\title{
SCREENING OF THYROID DYSFUNCTION IN PREGNANCY
}

\author{
Seena K. B ${ }^{1}$, Ajithkumar V. R2
}

${ }^{1}$ Assistant Professor, Department of Obstetrics and Gynaecology, Government Medical College, Thrissur. ${ }^{2}$ Assistant Professor, Department of Radiotherapy, Government Medical College, Thrissur.

\section{ABSTRACT}

\section{BACKGROUND}

The present study was mainly focussed on following parameters - 1) The thyroid disease burden in pregnant females in our hospital, 2) Types of thyroid disorders in pregnancy, 3) Complications in pregnancy and delivery in those with thyroid dysfunction and 4) Whether routine screening for thyroid disorders in pregnancy is advisable.

\section{MATERIALS AND METHODS}

300 pregnant women in the first trimester of pregnancy were randomly registered for the study at Department of Obstetrics and Gynaecology, Govt. Medical College, Hospital, Thrissur, Kerala. After getting ethical clearance and informed consent from patients, data are collected as per proforma and interview of patients in first trimester of pregnancy. Free T4, Free T3 and TSH levels and if necessary thyroid antibody levels are checked.

\section{RESULTS}

Patients are followed up till delivery and immediate postpartum period and results are analysed. Prevalence of hypothyroidism was $6.6 \%$ and that of hyperthyroidism was $1.6 \%$ in our study. Adverse maternal effects in the hypothyroid group were seen, of which preeclampsia was most significant. Adverse foetal outcomes were also noted in the hypothyroid group, of which intrauterine growth restriction was significant.

\section{CONCLUSION}

The prevalence of thyroid disorders was high in our study. Hence, to avoid the associated maternal and foetal consequences, routine screening of thyroid function in pregnancy is recommended.

\section{KEYWORDS}

Screening, Hypothyroidism, Hyperthyroidism, Pregnancy, First Trimester.

HOW TO CITE THIS ARTICLE: Seena KB, Ajithkumar VR. Screening of thyroid dysfunction in pregnancy. J. Evolution Med. Dent. Sci. 2017;6(19):1505-1507, DOI: 10.14260/Jemds/2017/330

\section{BACKGROUND}

Thyroid diseases have a strong predominance in women of child bearing age. ${ }^{1}$ Pregnancy produces an overall increase in thyroid activity, which allows the healthy individual to remain in a net euthyroid state. The prevalence of hypothyroidism is around 5 per 1000 in women and overt hypothyroidism is about 3/1000. The incidence of thyroid disease in pregnancy has been increasing in the last decade. This can have adverse effects on maternal and foetal health. ${ }^{2}$ Many of these could be prevented or ameliorated by early detection and appropriate treatment. This will only be possible if we implement screening for thyroid function during pregnancy. Hypothyroidism in pregnant women has been associated with complications like preeclampsia, preterm labour and post-partum haemorrhage. For the babies too, there are risks of foetal distress and congenital abnormalities. ${ }^{3}$

Graves' hyperthyroidism can lead to miscarriage, abruptio placentae, preterm labour and preeclampsia.

Financial or Other, Competing Interest: None.

Submission 13-01-2017, Peer Review 06-02-2017,

Acceptance 13-02-2017, Published 06-03-2017.

Corresponding Author:

Dr. Seena K. B,

Assistant Professor,

Department of Obstetrics and Gynaecology,

Government Medical College, Thrissur.

E-mail:devu666@yahoo.co.in

DOI: $10.14260 /$ jemds $/ 2017 / 330$
Postpartum thyroid dysfunction occurs within the first year after delivery and can manifest as hyper or hypothyroidism.

\section{MATERIALS AND METHODS}

They study was conducted in the department of Obstetrics and Gynaecology at Govt. Medical College, Thrissur between January 2013 and January 2014. A total of 300 patients from antenatal clinics were included. It was a prospective study. All healthy pregnant women with no other medical disorders and singleton pregnancies were included. Those with documented thyroid disorders, medical disorders or hyperemesis were excluded. After detailed history and examination, free T3, free T4 and TSH estimation were done in the first trimester for all these patients using the ELISA method. Those with abnormal thyroid function were made to undergo thyroid antibody testing were treated and followed up till termination of pregnancy. For those with abnormal thyroid function, tests were repeated 6 weekly and drug doses titrated accordingly. They were followed up throughout pregnancy.

Maternal outcome was noted in terms of preeclampsia, abruptio placentae, anaemia, gestational diabetes, incidence of caesarean section and postpartum haemorrhage. The foetal outcome was noted in terms of birth weight, Apgar score at one minute, neonatal intensive care unit admission, preterm delivery, Intrauterine Growth Restriction (IUGR), foetal distress and intrauterine demise. Neonatal outcomes were noted in terms of hyperbilirubinaemia, respiratory distress, 
sepsis, hypoglycaemia, hypothermia, intracranial bleed, necrotising enterocolitis and early neonatal death. Neonatal thyroid function estimation was also done.

\section{RESULTS}

The patients were divided into five groups according to the thyroid function test results.

Group I - Euthyroid, defined as normal TSH.

Group II - Subclinical hypothyroidism, ${ }^{4}$ defined as high TSH in presence of normal levels of free $\mathrm{T}_{4}$.

Group III - Overt hypothyroidism, defined as high TSH with low free $\mathrm{T}_{4}$.

Group IV - Overt hyperthyroidism defined as low TSH with raised free $\mathrm{T}_{4}$.

Group V - Subclinical hyperthyroidism, defined as low TSH with normal free $\mathrm{T}_{4}$.

Out of 300 patients, $25(8 \%)$ had deranged thyroid function. Prevalence of hypothyroidism was 20 (6.6\%), out of which 10 had overt hypothyroidism and 10 had subclinical hypothyroidism. One case of thyroid follicular carcinoma was detected in a case with overt hypothyroidism.

The prevalence of hyperthyroidism was $5(1.6 \%)$, out of which all 5 were overt hyperthyroid. Anti-TPO (Thyroid peroxidase) and ATA (Thyroglobulin antibody) were done in patients with deranged TSH levels.

Anti-TPO antibody was found positive in 10 of the hypothyroid patients (4 overt and 6 subclinical). ATA was positive in 5 hypothyroid patients ( 3 subclinical and 2 overt). Both were raised in three cases of hypothyroidism (2 subclinical and 1 overt). Thyroid antibodies were found negative in all 5 cases of hyperthyroidism.

Euthyroid (275), Subclinical hypothyroidism (10), Overt hypothyroidism (10), Overt hyperthyroidism (5).

\section{Adverse Maternal Effects}

Adverse maternal effects in the hypothyroidism group, which were significant was preeclampsia.

\begin{tabular}{|c|c|c|c|c|}
\hline & I (275) & I (10) & III (10) & IV (5) \\
\hline Preeclampsia & $15(5.45 \%)$ & $3(30 \%)^{*}$ & $2(10 \%)$ & - \\
\hline $\begin{array}{c}\text { Abruptio } \\
\text { Placenta }\end{array}$ & $6(2.18 \%)$ & 0 & $1(10 \%)$ & - \\
\hline Anaemia & $15(5.45 \%)$ & 0 & $1(10 \%)$ & - \\
\hline $\begin{array}{c}\text { Gestational } \\
\text { Diabetes }\end{array}$ & $37(13.45 \%)$ & 1 & $2(20 \%)$ & - \\
\hline $\begin{array}{c}\text { Postpartum } \\
\text { Haemorrhage }\end{array}$ & $13(4.73 \%)$ & 0 & $1(10 \%)$ & - \\
\hline
\end{tabular}

Table 1. Adverse Maternal Effects in various Groups

$\mathrm{P}<0.009$ (Gr I vs Gr II)

\section{Mode of Delivery}

Regarding mode of delivery in the different groups, LSCS for foetal distress was done in 3 out of the total 10 cases of subclinical hypothyroidism, which was significant.

\begin{tabular}{|c|c|c|c|c|}
\hline & I & II & III & IV \\
\hline LSCS & $86(31: 27 \%)$ & $6(60 \%)$ & $3(10 \%)$ & - \\
\hline $\begin{array}{c}\text { LSCS for } \\
\text { Foetal Distress }\end{array}$ & $10(3.64 \%)$ & $3(30 \%)^{*}$ & $1(10 \%)$ & - \\
\hline $\begin{array}{c}\text { Instrumental } \\
\text { Delivery }\end{array}$ & $18(6.55 \%)$ & $2(20 \%)$ & 0 & - \\
\hline $\begin{array}{c}\text { Normal } \\
\text { Vaginal }\end{array}$ & 163 & $2(20 \%)$ & 7 & 5 \\
\hline \multicolumn{4}{|c|}{ Table 2. Mode of Delivery in Different Groups } \\
\hline P < 0.002 (Gr I vs Gr II)
\end{tabular}

\section{Foetal Outcomes}

In the foetal outcome, adverse outcomes in overt hypothyroidism included 2 preterm births, 3 cases of IUGR (which was significant statistically), 2 cases of LBW (Low Birth Weight) and 2 cases of abortions. In the subclinical hypothyroidism group, there were 3 preterm births, 3 cases of IUGR, 1 case of LBW, 1 abortion and 1 still birth. No adverse outcomes were seen in the cases of hyperthyroidism.

\begin{tabular}{|c|c|c|c|c|}
\hline & I & II & III & IV \\
\hline Preterm & $57(20.7 \%)$ & $2(20 \%)$ & $3(310 \%)$ & 0 \\
\hline IUGR & $15(5.45 \%)$ & $3(30 \%)^{*}$ & $3(30 \%)$ & 0 \\
\hline LBW & $20(7.27 \%)$ & $2(20 \%)$ & $1(10 \%)$ & 0 \\
\hline Abortion & $8(2.91 \%)$ & $2(20 \%)$ & $1(10 \%)$ & 0 \\
\hline Stillbirth & $2(0.73 \%)$ & 0 & $1(10 \%)$ & 0 \\
\hline
\end{tabular}

Table 3. Foetal Outcomes in various Groups

$\mathrm{P}<0.029$ (Gr I vs Gr II)

\section{Neonatal Outcomes}

There were 3 cases of hyperthermia in the subclinical hypothyroid group, which was statistically significant; 1 case of RDS (Respiratory Distress Syndrome), 2 cases of low Apgar. In overt hypothyroid cases, there were 2 hyperthermia cases, 3 cases with low Apgar and 1 case of neonatal sepsis.

\begin{tabular}{|c|c|c|c|c|}
\hline & I & II & III & IV \\
\hline Hyperthermia & $10(3.64 \%)$ & $3(30 \%)^{*}$ & $2(20 \%)$ & 0 \\
\hline RDS & $8(2.9 \%)$ & $1(10 \%)$ & 0 & 0 \\
\hline Sepsis & $7(2.54 \%)$ & 0 & $1(10 \%)$ & 0 \\
\hline Low Apgar Score & $32(11.6 \%)$ & $2(20 \%)$ & $3(30 \%)$ & 0 \\
\hline \multicolumn{2}{|c|}{ Table 4. Neonatal Outcomes in various Groups } \\
\hline
\end{tabular}

$\mathrm{P}<0.003$ (Gr I vs Gr II)

\section{DISCUSSION}

Assessment of thyroid function during pregnancy should be done with a careful clinical evaluation of the patients symptoms and measurement of TSH and free thyroid hormones. ${ }^{5}$ Measurement of thyroid autoantibodies may be useful in selected cases to detect Graves' disease or Hashimoto's thyroiditis. ${ }^{6,7}$ Various studies have shown that targeted thyroid function testing would miss about $1 / 3$ of pregnant women with overt/subclinical hypothyroidism. ${ }^{8}$ Thus it is best to screen for thyroid dysfunction early in the pregnancy and treatment started at the earliest.

\section{CONCLUSION}

Out of 300 patients, 25 had deranged thyroid function; 20 had hypothyroidism and 5 had hyperthyroidism. AntiTPO antibody was positive in 10 of the hypothyroid patients (4 overt and 6 subclinical). Preeclampsia was significantly high in the hypothyroid group. Foetal distress was more for the subclinical hypothyroid. Preterm births and IUGR were also common foetal outcomes in the hypothyroid group.

\section{REFERENCES}

[1] Goodwin TM, Montoro M, Mestman JH. Transient hyperthyroidism and hyperemesis gravidarum: clinical aspects. Am J Obstet Gynecol 1992;167(3):648-52. 
[2] Stagnaro-Green A, Abalovich M, Alexander E, et al. Guidelines of the American thyroid association for the diagnosis and management of thyroid disease during pregnancy and postpartum. Thyroid 2011;21(10): 1081-125.

[3] Casey BM, Leveno KJ. Thyroid disease in pregnancy. Obstet Gynecol 2006;108(5):1283-92.

[4] Committee on Patient Safety and Quality Improvement. ACOG committee opinion no. 381: subclinical hypothyroidism in pregnancy. Obstet Gynecol 2007;110(4):959-60.
[5] Vaidya B, Anthony S, Bilous M, et al. Detection of thyroid dysfunction in early pregnancy: universal screening or targeted high-risk case finding? J Clin Endocrinol Metab 2007;92(1):203-7.

[6] Lazarus JH. Thyroid function in pregnancy. Br Med Bull 2011;97(1):137-48.

[7] Haddow JE, Palomaki GE, Allan WC, et al. Maternal thyroid deficiency during pregnancy and subsequent neuropsychological development of the child. N Eng J Med 1999;341(8):549-55.

[8] Lazarus JH, Kaklamanou M. Significance of low thyroidstimulating hormone in pregnancy. Current opinion in endocrinology diabetes and obesity 2007;14(5):389-92. 